\title{
Review Article \\ Controlling Self-Renewal and Differentiation of Stem Cells via Mechanical Cues
}

\author{
Michele M. Nava, Manuela T. Raimondi, and Riccardo Pietrabissa
}

LaBS, Department of Structural Engineering, Politecnico di Milano, 20133 Milano, Italy

Correspondence should be addressed to Michele M. Nava, nava@stru.polimi.it

Received 15 June 2012; Revised 20 July 2012; Accepted 23 July 2012

Academic Editor: Douglas W. Hamilton

Copyright ( $) 2012$ Michele M. Nava et al. This is an open access article distributed under the Creative Commons Attribution License, which permits unrestricted use, distribution, and reproduction in any medium, provided the original work is properly cited.

\begin{abstract}
The control of stem cell response in vitro, including self-renewal and lineage commitment, has been proved to be directed by mechanical cues, even in the absence of biochemical stimuli. Through integrin-mediated focal adhesions, cells are able to anchor onto the underlying substrate, sense the surrounding microenvironment, and react to its properties. Substrate-cell and cell-cell interactions activate specific mechanotransduction pathways that regulate stem cell fate. Mechanical factors, including substrate stiffness, surface nanotopography, microgeometry, and extracellular forces can all have significant influence on regulating stem cell activities. In this paper, we review all the most recent literature on the effect of purely mechanical cues on stem cell response, and we introduce the concept of "force isotropy" relevant to cytoskeletal forces and relevant to extracellular loads acting on cells, to provide an interpretation of how the effects of insoluble biophysical signals can be used to direct stem cells fate in vitro.
\end{abstract}

\section{Introduction}

Cell therapies represent the most challenging and, potentially, the most successful application of stem cells (SCs). SCs are defined as cells with the ability both to self-renew and to differentiate into specialized cells, in response to appropriate signals [1]. Because of their ability to differentiate into different types of functional cells, SCs posses great potential in therapeutics to restore and regenerate native tissues. A typical strategy based on SCs consists in engineering tissues by using cells coupled with suitable biomaterials to mimic the in vivo biochemical and biophysical microenvironment [2]; this approach has shown promising results in treating irreparable damage of native tissues caused by diseases or injuries [3]. However, before SC-based therapies are applied in clinics, a fundamental issue needs to be elucidated to gain a precise control over SCs response, in terms of self-renewal and differentiation, specifically, a broader understanding of the interplay between SCs, the surrounding microenvironment components (growth factors, cell-cell contacts, and cell-extracellular matrix interactions), and external forces [4], which is currently lacking.
Recent studies have shown that mechanical cues, including the stiffness of the substrate, the nanotopography of the adhesion surface, and extracellular forces, are able to direct stem cell fate in vitro, even in the absence of biochemical factors [5-7]. The goal of this paper is to offer a biomechanical perspective of the biological response of SCs to these cues; in particular, we describe the existing literature on the effects of purely mechanical cues on SC response in $v i t r o$, and we provide an interpretation of how these known factors can be used to control SC fate. To this purpose, we introduce the concept of "force isotropy" relevant to cytoskeletal forces and relevant to extracellular loads acting on cells.

\section{Stem Cell Sources}

Stem cells are characterized by two unique properties with respect to specialized cells; in vivo, they are able to divide by maintaining their stemness; this process is termed selfrenewal. Additionally, all stem cells retain the capacity to progressively differentiate into mature cell types. 


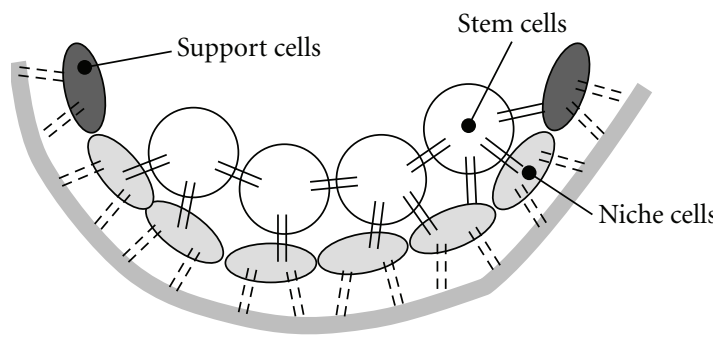

(a)

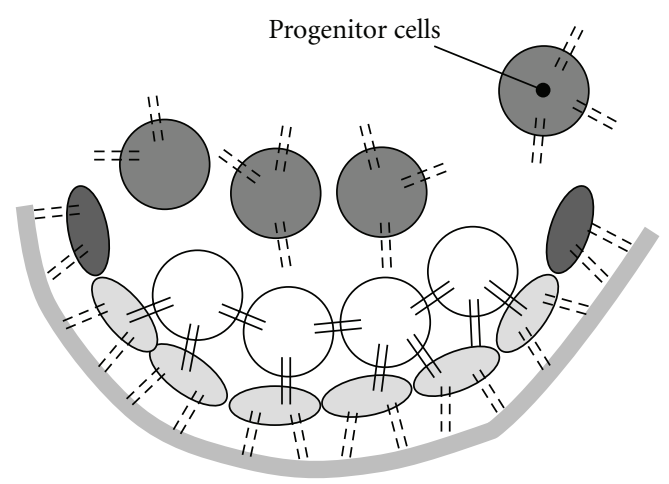

Lineage commitment

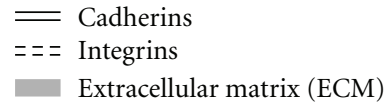

(c)

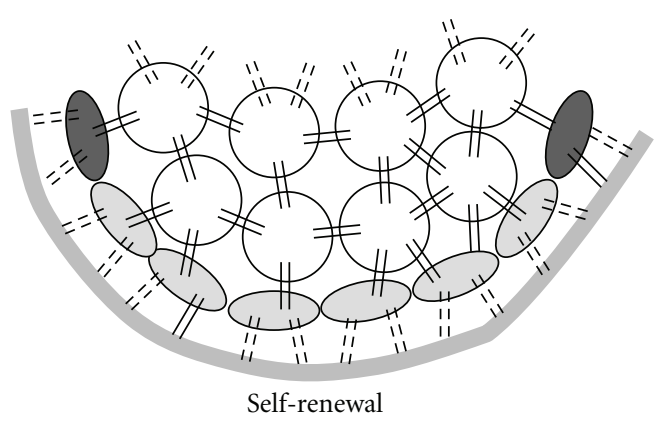

(b)
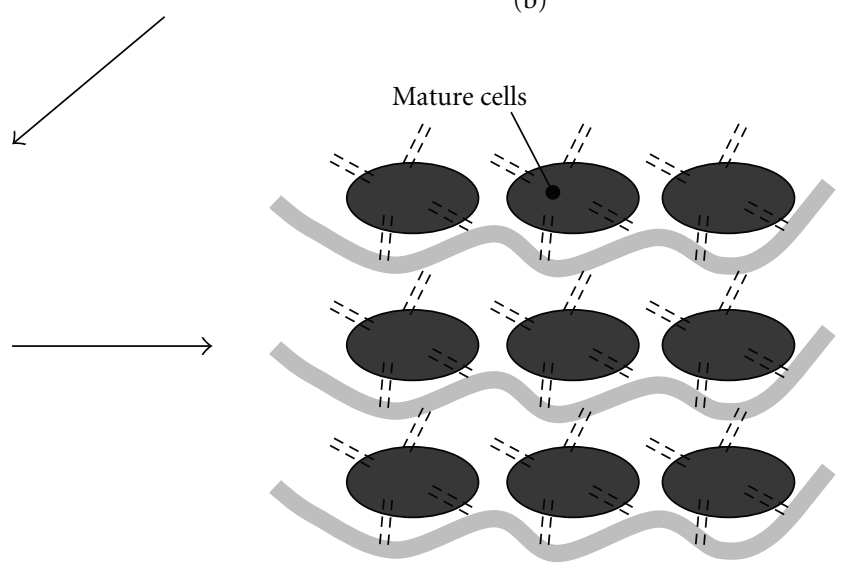

Terminal differentiation

$$
\begin{aligned}
\overline{=} & \text { Cadherins } \\
= \pm= & \text { Integrins } \\
& \text { Extracellular matrix }(\mathrm{ECM})
\end{aligned}
$$

(d)

FIGURE 1: The adult mammalian stem cell niche is defined as a microenvironment that facilitates (a) the survival and (b) the self-renewing capacity of the stem cells, as well as (c) the production of actively dividing precursors leading to the generation of a differentiated progeny. The stem cells retain their function as long as they remain anchored to the supporting cells and their divisions occur in such a way that one daughter cell keeps its contact with the supporting cell while the other one loses this contact, migrates from the niche, and (d) proceeds to generate terminally differentiated cells.

Stem cells are often classified into three categories, based on the source from which they are obtained.

(1) Embryonic stem cells (ESCs) are obtained from embryonic sources and were first isolated through the in vitro fertilization of preimplantation blastocysts [14]. They are characterized by their high telomerase activity and pluripotent differentiation potential.

(2) Adult stem cells (ASCs), such as mesenchymal stem cells (MSCs), are multipotent progenitor cells that can be isolated from a variety of adult tissues including bone marrow, bone, skin, blood vessels, and muscle [15]. They have been shown to differentiate into various cell types, characteristic of the tissues in which they reside [2]. ASCs in somatic tissues represent cellular stores capable of maintaining tissue homeostasis, regenerating tissue, and maintaining organ function [16].

(3) Induced pluripotent stem cells (iPS) are obtained by genetic reprogramming of somatic differentiated cells into a dedifferentiated state resembling embryonic stem cells [17-19]. These cells represent a promising method of obtaining autologous pluripotent stem cells sourced from adult tissues.

\section{The Stem Cell Niche}

The stem cell niche concept was firstly introduced in 1978 [20] and represents the natural microenvironment that surrounds stem cells; it can be defined as an anatomical and functional entity that plays a crucial role in maintaining tissue homeostasis and tissue repair and regeneration in case of injuries [16]. It is believed that the stem cell niche provides a complex array of physical signals, including cellcell contacts and cell-matrix adhesions, and biochemical signals, such as growth factors, to stem cells in a temporal and spatial manner; the integration of both local and systemic cues in the niche guides these cells to proliferation and fate specification $[21,22]$. 
The native stem cell niche (Figure 1(a)) consists of SCs adhered to a group of supporting cells, soluble environment factors at specific sites embedded in an extracellular matrix (ECM) serving as a mechanical support and also as a reservoir for cellular signalling molecules [23]. The ECM is composed of tissue-type-dependent fibrous structural proteins (collagens, fibronectin, laminin, elastin and vitronectin) and glycosaminoglycan (GAG) network. Collagen and elastin, networks provide tissue with mechanical resistance to shear and tensile stress. GAGs, thanks to the presence of hydrophilic groups in their backbone, provide the swollen of the matrix, and consequently, the compressive strength to the tissue. Cells interact with ECM components that contain various binding domains; these interactions occur through receptors known as integrins [24-27]. Furthermore, cells interact with neighboring cells through receptors referred to as cadherins. The regulation of SCs activities by its surrounding microenvironment is related to these receptors that act as physical anchors able to activate cell transduction pathways [28]. As long as SCs remain constrained to supporting cells, self-renewal occurs and stemness is maintained (Figure 1(b)); when cell division takes place, one daughter cell keeps in contact with the supporting cells while the other one adheres to the ECM, migrates from the niche (Figure 1(c)), and generates a lineage of committed cells (Figure 1(d)). A further important issue in the natural stem cell niche is represented by oxygen concentration, which is a critical component able to regulate SC commitment [29].

\section{Biochemical Control of Stem Cell Response}

Self-renewal and lineage commitment of SCs have shown to be influenced by several cues, which can be subdivided into two classes: biochemical cues and biophysical cues. Biochemical cues are provided by reciprocal interactions between the cell, soluble bioactive agents, and the ECM.

Soluble factors include growth factors, morphogenetic factors, cytokines, enzymes, and small cell-permeable molecules, such as transforming growth factors (TGF), bone morphogenetic protein (BMP), vitamin C, sodium pyruvate, retinoic acids (RAs), and other small molecules [30, 31]. These factors, when added to the cell culture, or secreted by stem cells or niche cells, diffuse and bind to cell membrane receptors activating cellular signal pathways able to alter SCs gene expression $[1,32]$.

Regarding the biochemical cues provided by the reciprocal interaction between the cell and the ECM, a strategy that has been developed to modulate cell attachment, proliferation, and differentiation consists in the use natural biopolymers to build scaffold materials [33-38]. Also synthetic biomaterials have been exploited. A property that has been shown to regulate SCs activity is chemical functionalisation of the substrate surface, for example, by anchoring monomers representing the ECM binding sites, including RGD and IKVAV [39-48], or other functional groups, for example, $-\mathrm{CH}_{3},-\mathrm{NH}_{2},-\mathrm{SH},-\mathrm{OH}$, and $-\mathrm{COOH}$ [49].
Even though the effect of biochemical cues, including soluble factors and ECM ligands [50-52], has been widely investigated in vitro, the regulation of self-renewal and lineage commitment of SCs by these key factors is still poorly understood and difficult to mimic; actually, in living systems, ECM components play a crucial role in the controlled delivery of molecular signalling molecules. Furthermore, the spatial and temporal organization of ECM adhesive ligands in vivo is finely tuned and difficult to achieve through engineering methods.

Besides applying strategies to control SC fate using biochemical factors, there is increasing evidence that mechanical factors are potent enough to control their fate in vitro. For instance, it has been demonstrated that the matrix elasticity can influence the lineage commitment of MSCs into neurons, osteoblasts, and myoblasts [53]. Other than the substrate stiffness, these mechanical factors include the surface topography of the biomaterial scaffold, its threedimensional (3D) geometry, and the external forces applied to cells $[4,54-56]$, as will be discussed in the next section.

\section{Mechanical Regulation of Stem Cell Fate}

Cells have the ability to actively sense their microenvironment and to react to the properties of their surroundings [57]. Anchorage-dependent cells are able to anchor onto the underlying substrate through focal adhesions formed by clusters of proteins, including integrins, that are transmembrane cell adhesion proteins [45]. The cell cytoskeleton, mechanically linked to the focal adhesions, is a network of filamentous proteins that extends throughout the cell cytoplasm in eukaryotic cells, and consists of actin, microtubules, and intermediate filaments [58]. The mechanical connections between the matrix and the cytoskeleton allow cells to exert traction forces that are transmitted to the cell nucleus through intracellular pathways; the resulting force triggers signalling transduction into biochemical signals that affect SC response, for example, the synthesis of specific transcription factors in the nucleus [59].

Various mechanotransduction pathways have been proposed, including the Ras/MAPK, the PI3K/Akt, RhoA $/$ ROCK, Wnt $/ \beta$-catenin, and the TGF- $\beta$ pathways, which are generally integrin-based, and mechano-sensitive ion channels. An extensive review of known mechanotransduction pathways can be found in [60].

\section{The Concept of "Force Isotropy"}

At the single cell level, cell adhesion to a material with specific engineering properties, such as surface nanotopography, stiffness, and microgeometry, can induce cytoskeletal tensional states due to the complex system of traction forces exerted by cells on the surrounding microenvironment; as mentioned above, these forces trigger signalling transduction cascades that provide intracellular events that regulate cell behaviour [61]. The cytoskeletal tensional state at the generic time point depends on the balance between the intracellular actomyosin contractility and the reaction forces exerted 


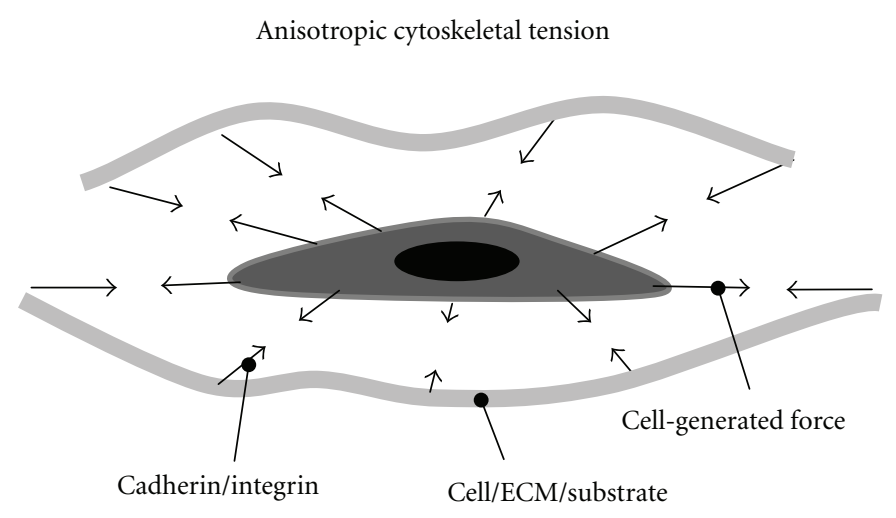

(a)

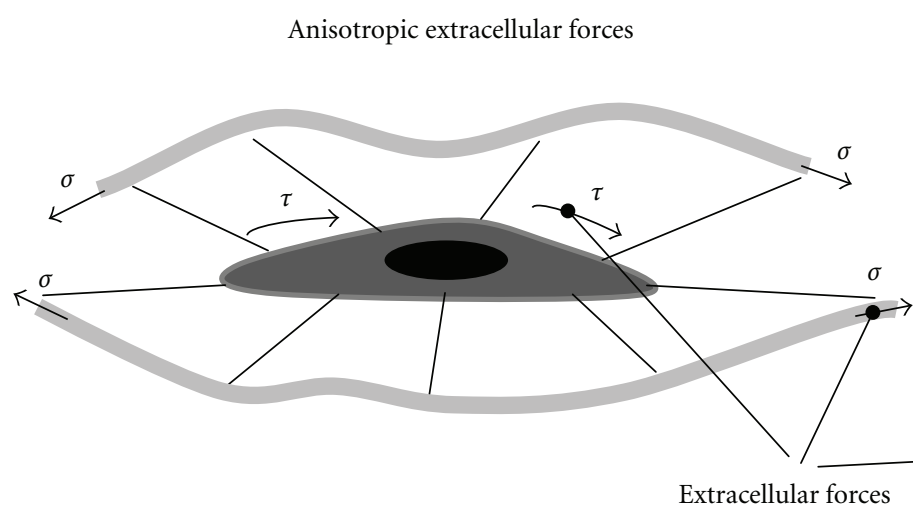

(c)

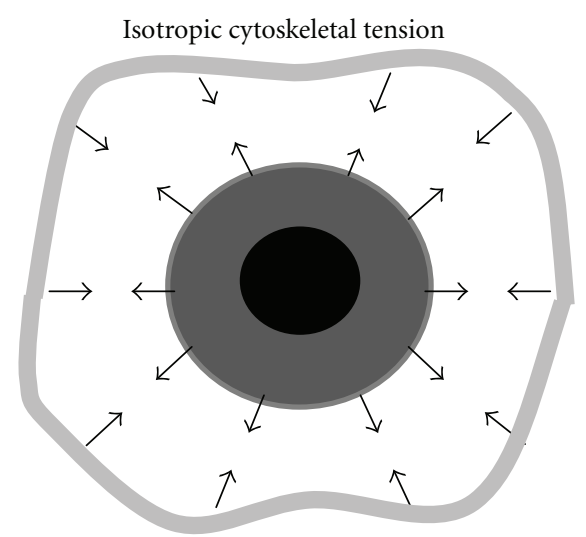

(b)

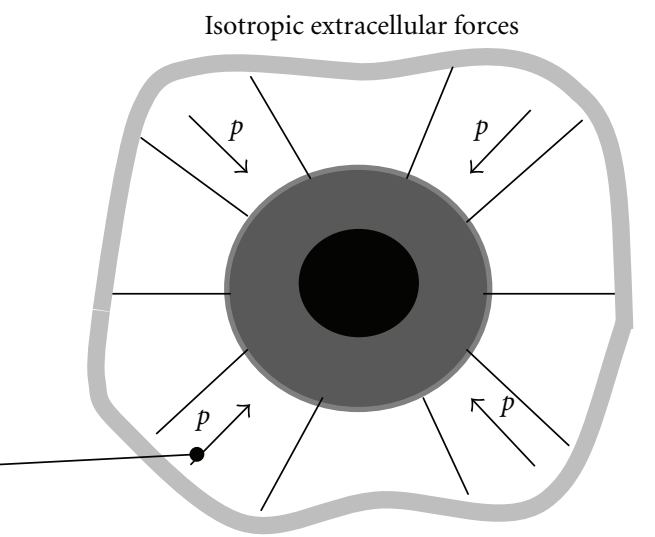

(d)

FIGURE 2: The concept of force isotropy applied to cells: (a) anisotropic and (b) isotropic cytoskeletal tension caused by cell contraction either in the niche, or during cell migration through the extracellular matrix; (c) anisotropic and (d) isotropic extracellular forces; $\sigma$ is cyclic matrix stress, $\tau$ is cyclic fluid-induced shear, and $p$ is cyclic pressurization.

by the underlying substrate, determined by its engineering properties. If cell adhesion-mediated traction forces, exerted by the cell on the matrix or adhesion substrate, have different magnitudes at varying spatial orientations, as shown by arrows in Figure 2(a), then the cell nucleus tends to elongate; this condition is what we define as "anisotropic cytoskeletal tension". On the contrary, isotropic cytoskeletal tension is characterized by adhesion-mediated traction forces of similar magnitude at varying orientation (Figure 2(b)); in this condition, the cell nucleus tends to maintain a roundish morphology.

In addition to the cytoskeletal tension related to cell adhesion, also extracellular forces are able to influence SC commitment [56]; extracellular forces, including pressurization of interstitial fluids, flow-induced shear, and matrix strain, are dynamically superimposed to the cell cytoskeletal tension in native tissue. The concept of force isotropy may well be extended to extracellular forces. When adhering cells are subjected to anisotropic loads, including cyclic tension or shear stress (Figure 2(c)), or to isotropic loads, such as cyclic hydrostatic pressure (Figure 2(d)), they will respond to these forces, which are superimposed to cytoskeletal tension, by dynamically varying the spatial distribution of focal adhesions, thus the nucleus shape. Increasing levels of anisotropy, both in terms of cytoskeletal tension and in terms of extracellular forces, can be obtained in vitro by applying engineering strategies, as will be discussed in the next section.

\section{Engineering Strategies to Mimic Force Isotropy States}

The ability of various types of cells to respond to mechanical differences in the extracellular environment has been thoroughly reviewed by Discher et al. $[4,54]$. The different engineering strategies developed to study how the cytoskeletal tension and extracellular forces affect SCs response are summarized below.

7.1. Substrate Stiffness. A biophysical factor that has been proved to strongly affect adult SC behaviour is the substrates stiffness [62]. By varying the mechanical properties of the matrix (Figures $3(\mathrm{a})$ and $3(\mathrm{~d})$ ), for example from soft to relatively rigid by controlling the level of polymer 


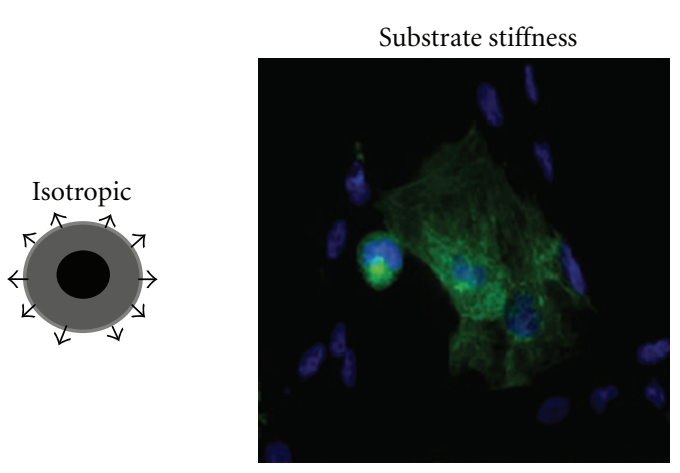

(a)

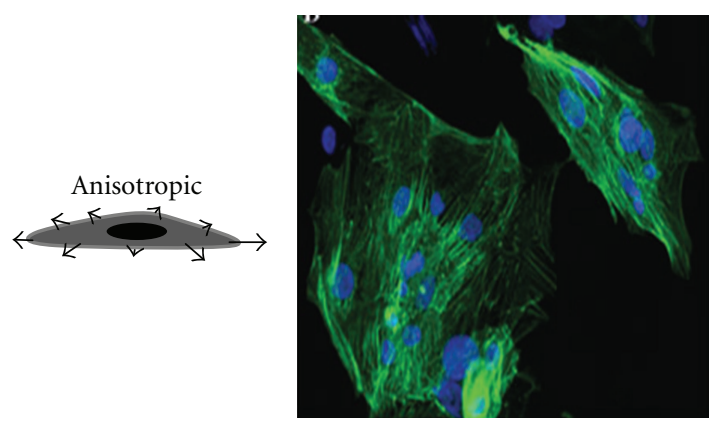

(d)

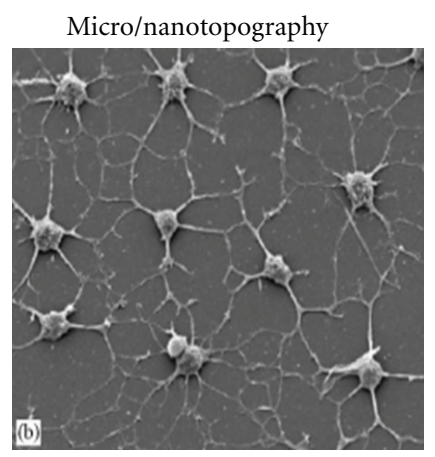

(b)

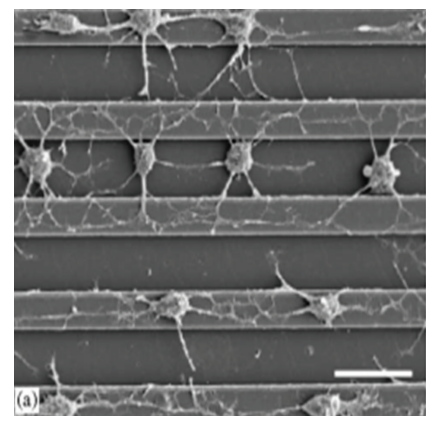

(e)

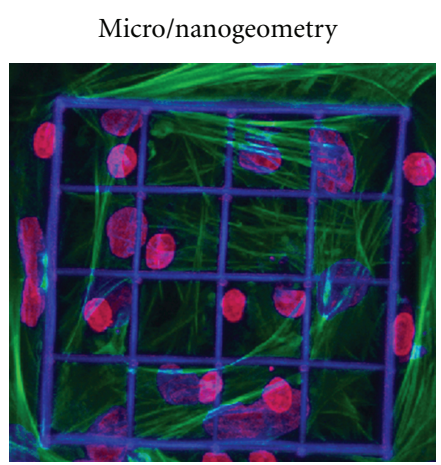

(c)

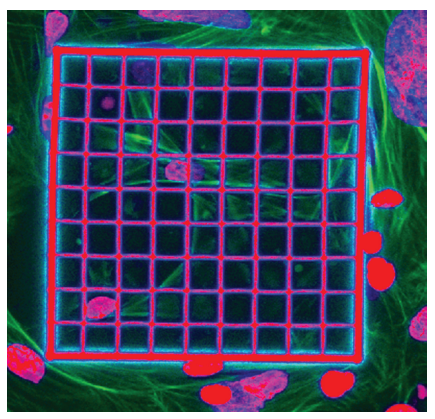

(f)

FIGURE 3: Examples of engineering strategies used to study the effects of anisotropic versus isotropic cytoskeletal tension on cultured stem cells. Substrates that mimic (a) soft versus (d) stiff ECM induce differential fates in human embryonic stem cell-derived cardiomyocytes, due to differential patterns of focal adhesions and actin-myosin stress fibres (in green, nuclei in blue). Reprinted and adapted from [8] with permission from John Wiley and Sons. In rat neural progenitor stem cells, (b) nonpatterned substrates induce formation of cell protrusions oriented randomly, while (e) micropatterned surfaces that mimic the native presentation and orientation of ECM proteins to cells induce alignment of elaborated processes in the direction of the grooves. Reprinted and adapted from [9] with permission from Elsevier. In rat mesenchymal stem cells, ultraprecise microscaffolds (c) with pore dimension of 20 microns allow for cell migration and isotropic attachment to the internal 3D lattice, whereas (f) for pores below 10 microns in size, cell migration into the scaffold pores is limited, inducing cell spreading on the top surface of the micro-scaffold (dividing nuclei in pink, cytoskeletal actin in green). Reprinted and adapted from [10] with permission from Elsevier.

crosslinking, it's possible to direct SC fate. Regarding MSCs, when they are cultured on soft substrates that mimic the elasticity of brain tissue (characterised by a stiffness of $0.1-$ $1 \mathrm{kPa}$, in terms of Young modulus), neuronal precursors were generated; matrices with intermediate stiffness mimicking muscle $(8-17 \mathrm{kPa})$ induced myogenic commitment while comparatively rigid matrices mimicking collagenous bone $(25-40 \mathrm{kPa})$ proved to direct osteogenic lineage $[8,53,63-$ $70]$.

Substrate stiffness was found to also strongly influence ESCs behaviour. For example, in [71] it has been found that cell spreading increases as a function of substrate stiffness. In a further study [72], in which a wide range of substrate stiffness was investigated (41-2700 kPa), it was assessed that mouse ESCs cultured for 5 days on softer substrates were able to self-renew even in the absence of leukemia inhibitory factor (LIF).

7.2. Nanotopography. Another key factor that has been demonstrated to direct self-renewal and commitment of SCs is the surface topography (Figures $3(\mathrm{~b})$ and $3(\mathrm{e})$ ) at the micro- or nano-scales (reviewed in Nikkhah et al. [73]). Various patterns combined with different adult SC types have been investigated: nanostructured surfaces [74, 75] affect self-renewal; nanogratings of $350 \mathrm{~nm}$ width compared to flat substrates can induce an upregulation on neuronal markers of MSCs [76] even in the absence of retinoic acid as a biochemical cue; neuronal commitment in human MSCs was also observed in nanofibrous scaffolds, with fibre diameter in the range of $230 \pm 31 \mathrm{~nm}$, using neural induction factors [77]. Myogenic commitment of MSCs in the absence of differentiating medium has been observed in aligned/nonaligned nanofibres having different average diameters [78] and in low roughness silk-tropoelastin scaffolds [79]. Grooves and grids, inducing cells alignment and elongation, show a greater effect on osteogenic differentiation compared to flat surfaces in MSCs [80-82]. Also random topographies have been exploited, including controlled disorder nanopits; the disordered ones were able to induce MSCs to differentiate towards osteogenic lineage [83-85]. The height of topographical features may influence MSCs differentiation [86] and adhesion [87]. In this study, the authors demonstrated that SC behaviour is a function 


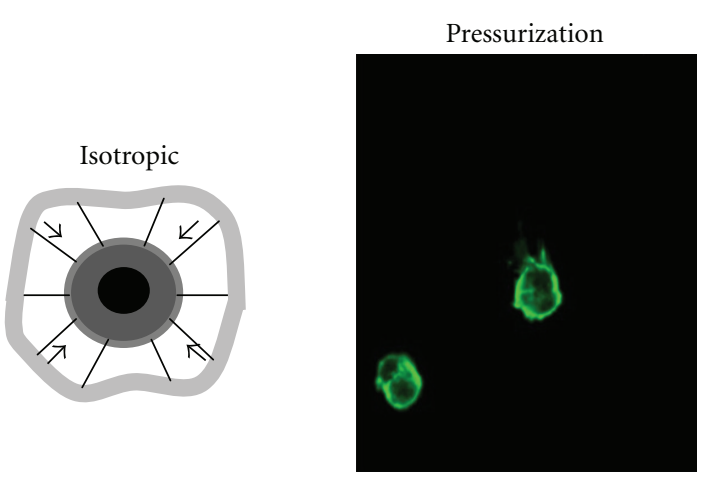

(a)

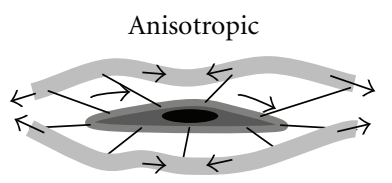

(d)

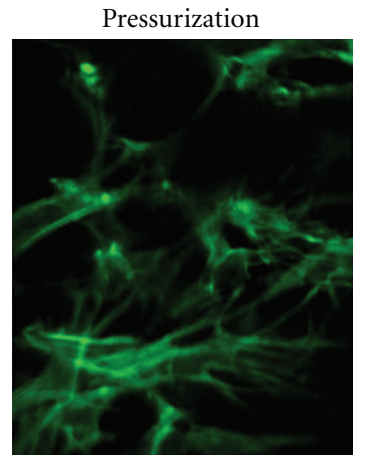

(b)

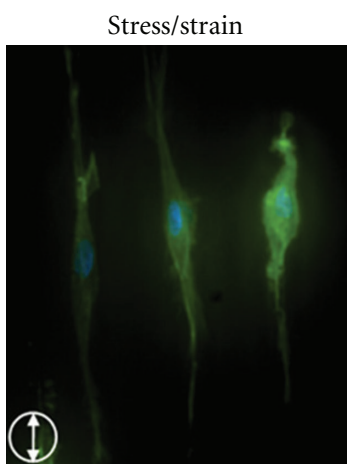

(e)

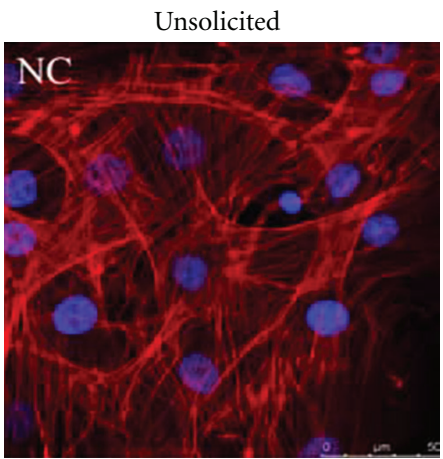

(c)

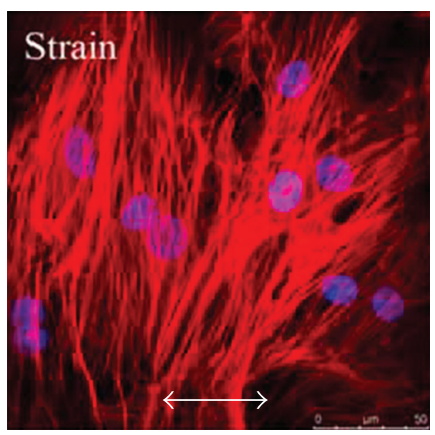

(f)

FIGURE 4: Examples of engineering strategies used to study the effects of anisotropic versus isotropic extracellular forces on cultured stem cells. Pig bone marrow-derived stem cells, subjected to cyclic hydrostatic pressure, (a) retain a spherical morphology when encapsulated in softer agarose, whereas (b) spread when encapsulated in stiffer fibrin hydrogels. Reprinted and adapted from [11] with permission from Elsevier. Rat bone marrow-derived stem cells (c) appear randomly distributed in unsolicited culture conditions, whereas (f) anisotropic strain induces cell elongation and upregulation of cardiomyocyte-related markers. Adapted with permission from [12]. In human bone marrow-derived mesenchymal stem cells and meniscal fibrochondrocytes cultured on a randomly organized nanofibrous scaffold, (d) biaxial strain induces a roundish shape of the cell nucleus, with small protrusion in all directions, while (e) uniaxial strain determines an elongated morphology of the cell nucleus. Reprinted and adapted from [13] with permission from Elsevier.

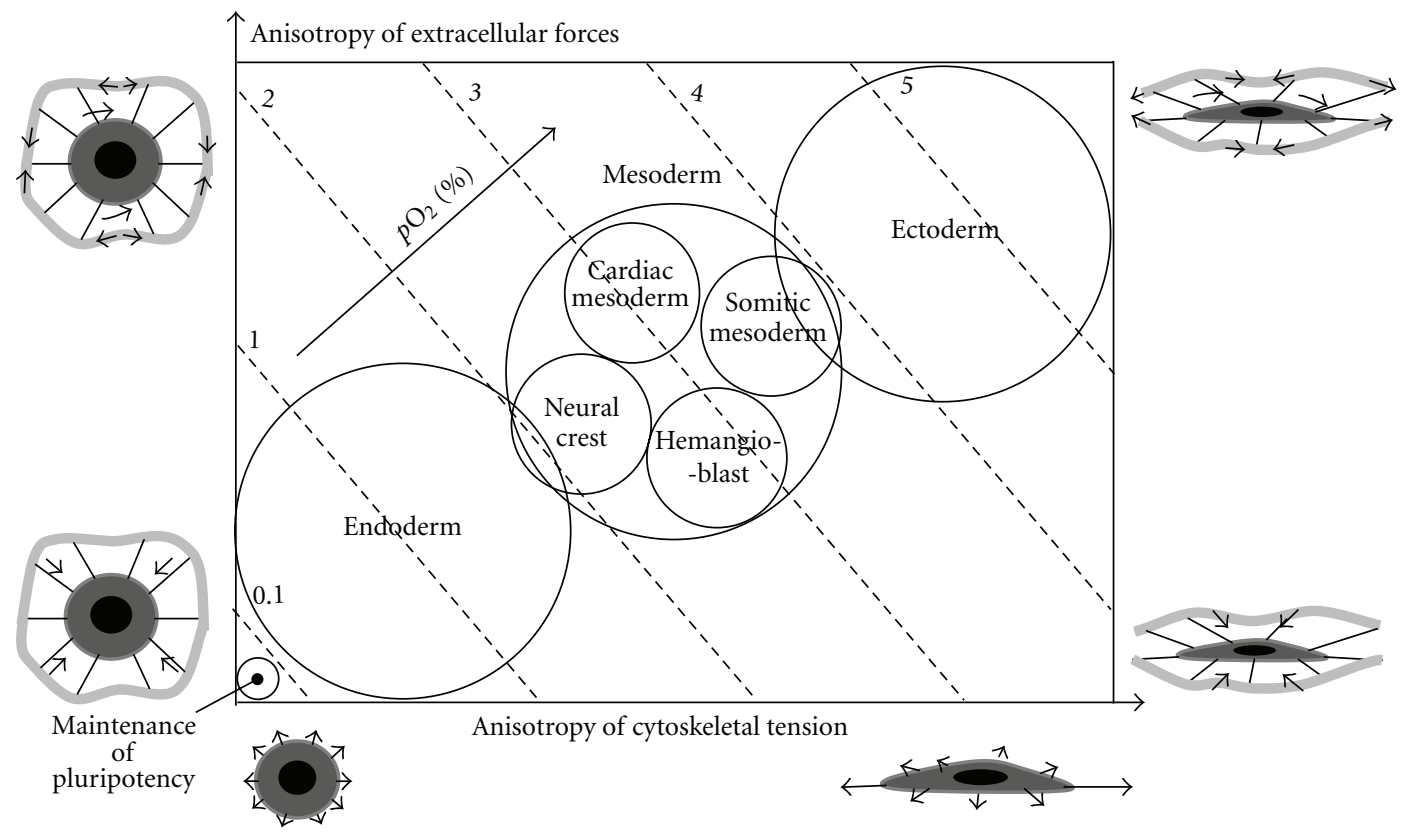

FIgURE 5: Synthesis of in vitro experimental evidence of the effects of mechanical cues and oxygen tension on embryonic stem cell fate. 


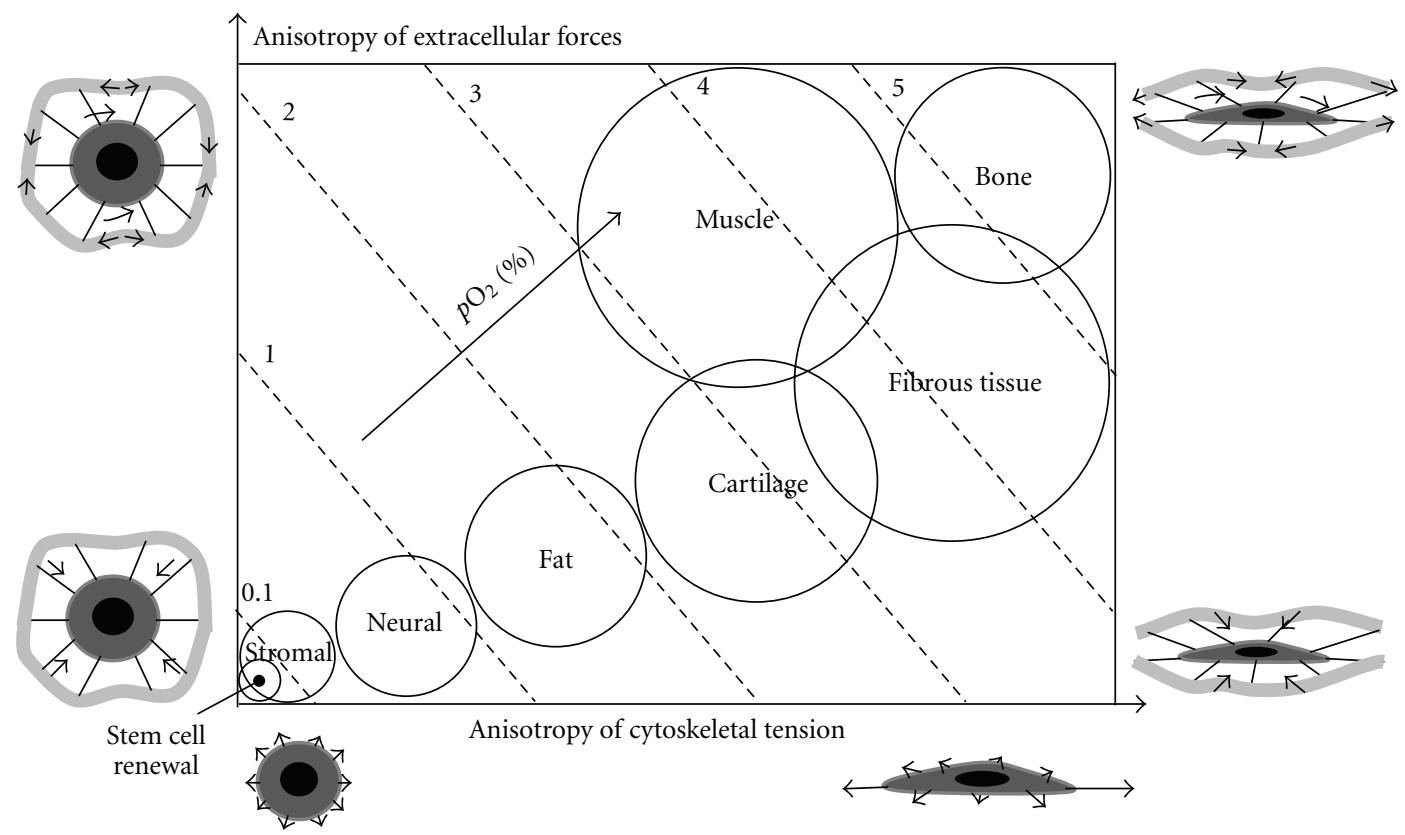

FIGURE 6: Synthesis of in vitro experimental evidence of the effects of mechanical cues and oxygen tension on the fate of mesenchymal stem cells derived from the endosteal compartment.

of pillar height and not of the diameter or gaps between nanopits. The pattern shape has been proved to regulate MSCs activities: in [88] round patterns aided adipogenic lineage differentiation while gratings induced elongation and osteogenic transition; also, in [89-92] geometric-specific proliferation and differentiation patterns were observed.

Regarding neuronal progenitor SCs, nanofibres of various size have been investigated and it was observed that cells grown on these fibres were able to differentiate into oligodendrocytes. The proliferation rate increased on smaller fibre diameter [55]. Neural differentiation was observed on grooves chemically modified with laminin [9] (Figures 3(b) and $3(\mathrm{e}))$.

Nano/microtopography has shown to affect also ESCs behaviour. In [93] mouse ES cell differentiation can be observed when these cells are cultured in the form of embryoid bodies. ESC morphology, including elongation, alignment, and proliferation can be induced by nanoscale grating features [94]. Micro- and nanopatterns of various geometries and sizes to study ESCs response have been exploited [95]; for example, in [96], circular micro domains $(200 \mu \mathrm{m}$ in diameter) were found to direct cardiac differentiation of uniform-sized mouse ESC aggregates. Also nanofibres have been investigated and it has been shown that they induce an upregulation of early development osteogenic markers [97].

7.3. Microgeometry. The three-dimensional (3D) microgeometry of the culture environment strongly contributes to direct cell phenotype [98]. Traditionally, mammalian and SCs have been cultured on $2 \mathrm{D}$ substrates. Differences in cell behaviour, including adhesion, migration, proliferation, and gene expression, have been observed between 2D and 3D cultures. For instance, 2D culture confines cells to a planar environment and restricts the more complex morphologies observed in vivo; cells are able to interact through a limited membrane segment with the underlying substrate and neighbouring cells $[99,100]$. As a consequence, the mechanotransduction process and the interaction with nutrients, soluble factors, and mechanical cues are altered [101]. These considerations lead an increasing interest in the development of truly $3 \mathrm{D}$ scaffolds to mimic the native environment in which cells reside [102]. Different 3D cell culture supports have been developed, including nanofibres, hydrogels, microwells, and other more complex structures (Figures 3(c) and 3(f)). Nanofibrous scaffolds were able to mimic the architecture formed by fibrillar ECM proteins $[103,104]$. Another approach to surround cells with a truly $3 \mathrm{D}$ environment consists in suspending them in a hydrogel; for example, in [105] osteogenic commitment of rat MSC has been observed in these gels, although in the presence of osteoinductive medium. Very recently, photocurable materials have been used to fabricate 3D scaffolds by two-photon polymerization, a 3D microfabrication technique that allows to fabricate ordered microstructures having a submicron spatial resolution [106, 107]. Cell viability [108], homing, and proliferation were promoted by culturing MSCs on these structures $[10,109]$.

7.4. External Forces. Mechanical forces play an important role in SC adhesion, spreading, proliferation, migration, and differentiation [56]. External forces applied to the cell are able to influence the intracellular cytoskeletal arrangement thus regulating nuclear shape and cell activities. It is difficult to precisely determine the biomechanical and biochemical 
mechanisms in vivo related to the cytoskeletal conformational changes. Biomimetic mechanical stimulation, including compression, stretching, and fluid-induced shear stress, have, therefore, been used to investigate these mechanisms in vitro [110].

Cyclic compression is able to alter MSC phenotype. MSCs subjected to dynamic compression or hydrostatic pressure (Figures 4(a)-4(c)) induced an increase of chondrocyte lineage markers and enhanced ECM deposition [111, 112].

Mechanical strain from applied loading, either unidirectional or biaxial (Figures 4(d)-4(f)), can direct specific stem cell lineages. For example, cyclic stretch has been demonstrated to commit MSCs to a myogenic phenotype [113] and mouse ESCs to a vascular smooth muscle cell phenotype [114]. Mechanical strain can also increase proliferation and inhibit differentiation in mouse and human ESCs [115], as well as promote cell alignment with respect to the direction of the strain [116].

Fluid-induced shear has a significant impact on the fate of SCs, as well. In two-dimensional (2D) systems, it induces osteogenic differentiation by activating multiple intracellular signalling pathways [117].

\section{Mechanical Control of Stem Cell Response}

In this section we provide a tentative interpretation of how mechanical cues can be used to control SC fate by applying the concept of force isotropy to synthesise the existing literature of this field.

8.1. Embryonic Stem Cells. As shown in various studies, a typical approach to mimic in vitro the native microenvironment of ESC consists in confining them, by the use of microwells or microarrays having different dimension and shape, in the aim of allowing them to form 3D microaggregates; using this method, it has been observed that higher cell densities induce cell self-renewal and maintenance of pluripotency $[118,119]$.

Cells cultured in aggregates are characterized by a maximized cell-to-cell contact, which induces a highly isotropic cytoskeletal tension, resulting in a roundish nuclear morphology, and by low levels of oxygen concentration (Figure 5). Based on the existing literature, at lower levels of anisotropy of cytoskeletal tension, ESCs commit toward endoderm and mesoderm, specifically neuronal [120], cardiomyogenic [27, 96], and haematopoietic [121]. A highly anisotropic cytoskeletal tension directs ectodermal lineage [118].

8.2. Adult Stem Cells. The most studied SC type in mechanobiology are MSCs, due to their very high sensitivity to mechanical stimuli. By making a synthesis of the existing literature $[67,69,88,89,91,92]$, it can be noted that a highly isotropic cytoskeletal tension, combined with a low oxygen concentration and with very low extracellular loads, synergistically promote MSCs self-renewal and maintenance of pluripotency (Figure 6). For example, in a study by Winer et al. [67], human MSCs cultured on hydrogels having a stiffness comparable to bone marrow $(0.25 \mathrm{kPa})$, have shown to self-renew and maintain pluripotency, if compared to cells cultured on more rigid substrates.

Coherently, the existing literature shows that the increase in anisotropy of cytoskeletal forces reduces pluripotency and enhances MSCs lineage commitment. For example, neural precursor cells can be obtained from MSCs by using nano/micropatterned surfaces, including nanofibres and gratings, and/or substrate having a very low stiffness, comparable to that of the brain ECM [53, 55, 76, 77]. All these engineering strategies result in substrates which induce an isotropic cytoskeletal tension, resulting in a very roundish morphology of the cell nucleus.

SC commitment can be induced by applying biophysical cues in a synergistic manner; actually, the superimposition of extracellular loads to cells, having their own cytoskeletal tension state due to adhesive forces, can alter and regulate their fate. MSCs can express various phenotypes including fat, cartilage, muscle, fibrous tissue, and bone. Fibrous tissues, such as tendon, could be obtained by anisotropic traction forces exerted by cells and through the superimposition of anisotropic extracellular loading, such as mechanical stretching [122-124]. Myogenic and cardiomyogenic precursor cells have been obtained through a combination of different types of directional (anisotropic) extracellular loading, such as shear stress and cyclic strain, in 2D systems [12]. Chondrogenic lineage can be achieved by a combination of intrinsic factors (e.g., a moderate substrate stiffness) and isotropic extracellular loads, including cyclic pressurisation and shear stress, as shown in [125]. Regarding adipogenic lineage commitment, it is inhibited by anisotropic extracellular forces like mechanical strain [126], and favoured by isotropic-inducing factors such as a very low substrate stiffness, or a low cell density [92].

\section{Conclusion}

To gain a precise control over SC response and make successful translation of SC-based therapies to the clinics, the contribution of mechanical factors on SC response must be elucidated and quantified. In this paper, we have analysed the existing knowledge in this field, and we have introduced the concept of "force isotropy," as a first step towards the interpretation of the existing knowledge. Further research, in which biomechanical cues will be applied in a synergistic manner on truly 3D microenvironments, will likely provide a broader understanding of SC response to these cues.

\section{Acknowledgments}

Our research is founded by the following grants: " $5 \times 1000$ 2009 CUPD41J10000490001" (Politecnico di Milano), "Biosensors and Artificial Bio-systems" (Italian Institute of Technology-iiT, Genova), Cariplo 2010 “3D Micro structuring and Functionalisation of Polymeric Materials for Scaffolds in Regenerative Medicine" (Cariplo Foundation, Milano). 


\section{References}

[1] S. Ding and P. G. Schultz, "A role for chemistry in stem cell biology," Nature Biotechnology, vol. 22, no. 7, pp. 833-840, 2004.

[2] A. Atala, R. Lanza, J. A. Thomson, and R. M. Nerem, Principles of Regenerative Medicine, vol. 1448, Elsevier, Burlington, Mass, USA, 2008.

[3] P. Macchiarini, P. Jungebluth, T. Go et al., "Clinical transplantation of a tissue-engineered airway," The Lancet, vol. 372, no. 9655, pp. 2023-2030, 2008.

[4] D. E. Discher, D. J. Mooney, and P. W. Zandstra, "Growth factors, matrices, and forces combine and control stem cells," Science, vol. 324, no. 5935, pp. 1673-1677, 2009.

[5] A. B. Castillo and C. R. Jacobs, "Mesenchymal stem cell mechanobiology," Current Osteoporosis Reports, vol. 8, no. 2, pp. 98-104, 2010.

[6] G. C. Reilly and A. J. Engler, "Intrinsic extracellular matrix properties regulate stem cell differentiation," Journal of Biomechanics, vol. 43, no. 1, pp. 55-62, 2010.

[7] D. A. Lee, M. M. Knight, J. J. Campbell, and D. L. Bader, "Stem cell mechanobiology," Journal of Cellular Biochemistry, vol. 112, no. 1, pp. 1-9, 2011.

[8] J. G. Jacot, H. Kita-Matsuo, K. A. Wei et al., "Cardiac myocyte force development during differentiation and maturation," Annals of the New York Academy of Sciences, vol. 1188, pp. 121-127, 2010.

[9] J. B. Recknor, D. S. Sakaguchi, and S. K. Mallapragada, "Directed growth and selective differentiation of neural progenitor cells on micropatterned polymer substrates," Biomaterials, vol. 27, no. 22, pp. 4098-4108, 2006.

[10] M. T. Raimondi, S. M. Eaton, M. Laganà et al., "Threedimensional structural niches engineered via two-photon laser polymerization promote stem cell homing," Acta Biomaterialia. In press.

[11] A. J. Steward, S. D. Thorpe, T. Vinardell, C. T. Buckley, D. R. Wagner, and D. J. Kelly, "Cell-matrix interactions regulate mesenchymal stem cell response to hydrostatic pressure," Acta Biomaterialia, vol. 8, no. 6, pp. 2153-2159, 2012.

[12] Y. Huang, L. Zheng, X. Gong et al., "Effect of cyclic strain on cardiomyogenic differentiation of rat bone marrow derived mesenchymal stem cells," PLoS ONE, vol. 7, no. 4, Article ID e34960, 2012.

[13] A. S. Nathan, B. M. Baker, N. L. Nerurkar, and R. L. Mauck, "Mechano-topographic modulation of stem cell nuclear shape on nanofibrous scaffolds," Acta Biomaterialia, vol. 7, no. 1, pp. 57-66, 2011.

[14] J. A. Thomson, "Embryonic stem cell lines derived from human blastocysts," Science, vol. 282, no. 5391, pp. 1145 1147, 1998.

[15] N. S. Hwang, S. Varghese, and J. Elisseeff, "Controlled differentiation of stem cells," Advanced Drug Delivery Reviews, vol. 60, no. 2, pp. 199-214, 2008.

[16] M. R. Walker, K. K. Patel, and T. S. Stappenbeck, "The stem cell niche," Journal of Pathology, vol. 217, no. 2, pp. 169-180, 2009.

[17] K. Takahashi and S. Yamanaka, "Induction of pluripotent stem cells from mouse embryonic and adult fibroblast cultures by defined factors," Cell, vol. 126, no. 4, pp. 663-676, 2006.

[18] K. Okita, T. Ichisaka, and S. Yamanaka, "Generation of germline-competent induced pluripotent stem cells," Nature, vol. 448, no. 7151, pp. 313-317, 2007.
[19] J. Yu, M. A. Vodyanik, K. Smuga-Otto et al., "Induced pluripotent stem cell lines derived from human somatic cells," Science, vol. 318, no. 5858, pp. 1917-1920, 2007.

[20] R. Schofield, "The relationship between the spleen colonyforming cell and the haemopoietic stem cell. A hypothesis," Blood Cells, vol. 4, no. 1-2, pp. 7-25, 1978.

[21] E. Fuchs, T. Tumbar, and G. Guasch, "Socializing with the neighbors: stem cells and their niche," Cell, vol. 116, no. 6, pp. 769-778, 2004.

[22] K. A. Moore and I. R. Lemischka, "Stem cells and their niches," Science, vol. 311, no. 5769, pp. 1880-1885, 2006.

[23] W. P. Daley, S. B. Peters, and M. Larsen, "Extracellular matrix dynamics in development and regenerative medicine," Journal of Cell Science, vol. 121, no. 3, pp. 255-264, 2008.

[24] S. Li, D. Harrison, S. Carbonetto et al., "Matrix assembly, regulation, and survival functions of laminin and its receptors in embryonic stem cell differentiation," Journal of Cell Biology, vol. 157, no. 7, pp. 1279-1290, 2002.

[25] P. D. Yurchenco and W. G. Wadsworth, "Assembly and tissue functions of early embryonic laminins and netrins," Current Opinion in Cell Biology, vol. 16, no. 5, pp. 572-579, 2004.

[26] N. Gersdorff, M. Müller, S. Otto, R. Poschadel, S. Hübner, and N. Miosge, "Basement membrane composition in the early mouse embryo day 7," Developmental Dynamics, vol. 233, no. 3, pp. 1140-1148, 2005.

[27] A. J. Engler, P. O. Humbert, B. Wehrle-Haller, and V. M. Weaver, "Multiscale modeling of form and function," Science, vol. 324, no. 5924, pp. 208-212, 2009.

[28] A. Page-McCaw, A. J. Ewald, and Z. Werb, "Matrix metalloproteinases and the regulation of tissue remodelling," Nature Reviews Molecular Cell Biology, vol. 8, no. 3, pp. 221-233, 2007.

[29] A. Mohyeldin, T. Garzón-Muvdi, and A. Quiñones-Hinojosa, "Oxygen in stem cell biology: a critical component of the stem cell niche," Cell Stem Cell, vol. 7, no. 2, pp. 150-161, 2010.

[30] J. Kawaguchi, P. J. Mee, and A. G. Smith, "Osteogenic and chondrogenic differentiation of embryonic stem cells in response to specific growth factors," Bone, vol. 36, no. 5, pp. 758-769, 2005.

[31] H. Zhang, S. Dai, J. Bi, and K.-K. Liu, "Biomimetic threedimensional microenvironment for controlling stem cell fate," Interface Focus, vol. 1, no. 5, pp. 792-803, 2011.

[32] Z. J. Liu, Y. Zhuge, and O. C. Velazquez, "Trafficking and differentiation of mesenchymal stem cells," Journal of Cellular Biochemistry, vol. 106, no. 6, pp. 984-991, 2009.

[33] H. A. Awad, M. Q. Wickham, H. A. Leddy, J. M. Gimble, and F. Guilak, "Chondrogenic differentiation of adipose-derived adult stem cells in agarose, alginate, and gelatin scaffolds," Biomaterials, vol. 25, no. 16, pp. 3211-3222, 2004.

[34] A. Yokoyama, I. Sekiya, K. Miyazaki, S. Ichinose, Y. Hata, and T. Muneta, "In vitro cartilage formation of composites of synovium-derived mesenchymal stem cells with collagen gel," Cell and Tissue Research, vol. 322, no. 2, pp. 289-298, 2005.

[35] N. Datta, Q. P. Pham, U. Sharma, V. I. Sikavitsas, J. A. Jansen, and A. G. Mikos, "In vitro generated extracellular matrix and fluid shear stress synergistically enhance 3D osteoblastic differentiation," Proceedings of the National Academy of Sciences of the United States of America, vol. 103, no. 8, pp. 2488-2493, 2006.

[36] U. Nöth, L. Rackwitz, A. Heymer et al., "Chondrogenic differentiation of human mesenchymal stem cells in collagen 
type I hydrogels," Journal of Biomedical Materials Research A, vol. 83, no. 3, pp. 626-635, 2007.

[37] K. Brännvall, K. Bergman, U. Wallenquist et al., "Enhanced neuronal differentiation in a three-dimensional collagenhyaluronan matrix," Journal of Neuroscience Research, vol. 85, no. 10, pp. 2138-2146, 2007.

[38] C. Chung and J. A. Burdick, "Influence of three-dimensional hyaluronic acid microenvironments on mesenchymal stem cell chondrogenesis," Tissue Engineering A, vol. 15, no. 2, pp. 243-254, 2009.

[39] M. D. Pierschbacher and E. Ruoslahti, "Influence of stereochemistry of the sequence Arg-Gly-Asp-Xaa on binding specificity in cell adhesion," Journal of Biological Chemistry, vol. 262, no. 36, pp. 17294-17298, 1987.

[40] P. D. Drumheller and J. A. Hubbell, "Polymer networks with grafted cell adhesion peptides for highly biospecific cell adhesive substrates," Analytical Biochemistry, vol. 222, no. 2, pp. 380-388, 1994.

[41] Y. Wan, J. Yang, J. Yang, J. Bei, and S. Wang, "Cell adhesion on gaseous plasma modified poly-(L-lactide) surface under shear stress field," Biomaterials, vol. 24, no. 21, pp. 37573764, 2003.

[42] E. Lieb, J. Tessmar, M. Hacker et al., "Poly(D,L-lactic acid)poly(ethylene glycol)-monomethyl ether diblock copolymers control adhesion and osteoblastic differentiation of marrow stromal cells," Tissue Engineering, vol. 9, no. 1, pp. 71-84, 2003.

[43] G. A. Silva, C. Czeisler, K. L. Niece et al., "Selective differentiation of neural progenitor cells by high-epitope density nanofibers," Science, vol. 303, no. 5662, pp. 13521355, 2004.

[44] B. G. Keselowsky, D. M. Collard, and A. J. García, "Integrin binding specificity regulates biomaterial surface chemistry effects on cell differentiation," Proceedings of the National Academy of Sciences of the United States of America, vol. 102, no. 17, pp. 5953-5957, 2005.

[45] M. P. Lutolf and J. A. Hubbell, "Synthetic biomaterials as instructive extracellular microenvironments for morphogenesis in tissue engineering," Nature Biotechnology, vol. 23, no. 1, pp. 47-55, 2005.

[46] N. S. Hwang, S. Varghese, Z. Zhang, and J. Elisseeff, "Chondrogenic differentiation of human embryonic stem cellderived cells in arginine-glycine-aspartate-modified hydrogels," Tissue Engineering, vol. 12, no. 9, pp. 2695-2706, 2006.

[47] L. Y. Santiago, R. W. Nowak, J. P. Rubin, and K. G. Marra, "Peptide-surface modification of poly(caprolactone) with laminin-derived sequences for adipose-derived stem cell applications," Biomaterials, vol. 27, no. 15, pp. 2962-2969, 2006.

[48] C. N. Salinas and K. S. Anseth, "Decorin moieties tethered into PEG networks induce chondrogenesis of human mesenchymal stem cells," Journal of Biomedical Materials Research A, vol. 90, no. 2, pp. 456-464, 2009.

[49] J. M. Curran, R. Chen, and J. A. Hunt, "Controlling the phenotype and function of mesenchymal stem cells in vitro by adhesion to silane-modified clean glass surfaces," Biomaterials, vol. 26, no. 34, pp. 7057-7067, 2005.

[50] D. S. W. Benoit and K. S. Anseth, "The effect on osteoblast function of colocalized RGD and PHSRN epitopes on PEG surfaces," Biomaterials, vol. 26, no. 25, pp. 5209-5220, 2005.

[51] F. Yang, C. G. Williams, D. A. Wang, H. Lee, P. N. Manson, and J. Elisseeff, "The effect of incorporating RGD adhesive peptide in polyethylene glycol diacrylate hydrogel on osteogenesis of bone marrow stromal cells," Biomaterials, vol. 26, no. 30, pp. 5991-5998, 2005.

[52] D. S. W. Benoit, M. P. Schwartz, A. R. Durney, and K. S. Anseth, "Small functional groups for controlled differentiation of hydrogel-encapsulated human mesenchymal stem cells," Nature Materials, vol. 7, no. 10, pp. 816-823, 2008.

[53] A. J. Engler, S. Sen, H. L. Sweeney, and D. E. Discher, "Matrix elasticity directs stem cell lineage specification," Cell, vol. 126, no. 4, pp. 677-689, 2006.

[54] D. E. Discher, P. Janmey, and Y. L. Wang, "Tissue cells feel and respond to the stiffness of their substrate," Science, vol. 310, no. 5751, pp. 1139-1143, 2005.

[55] G. T. Christopherson, H. Song, and H. Q. Mao, "The influence of fiber diameter of electrospun substrates on neural stem cell differentiation and proliferation," Biomaterials, vol. 30, no. 4, pp. 556-564, 2009.

[56] F. Guilak, D. M. Cohen, B. T. Estes, J. M. Gimble, W. Liedtke, and C. S. Chen, "Control of stem cell fate by physical interactions with the extracellular matrix," Cell Stem Cell, vol. 5, no. 1, pp. 17-26, 2009.

[57] S. A. Kress, B. Weyand, and C. Kasper, "Stem cell differentiation depending on different surfaces," Advances in Biochemical Engineering/Biotechnology, vol. 126, pp. 263-283, 2012.

[58] B. Geiger, J. P. Spatz, and A. D. Bershadsky, "Environmental sensing through focal adhesions," Nature Reviews Molecular Cell Biology, vol. 10, no. 1, pp. 21-33, 2009.

[59] N. Wang, J. D. Tytell, and D. E. Ingber, "Mechanotransduction at a distance: mechanically coupling the extracellular matrix with the nucleus," Nature Reviews Molecular Cell Biology, vol. 10, no. 1, pp. 75-82, 2009.

[60] Y. Sun, C. S. Chen, and J. Fu, "Forcing stem cells to behave: a biophysical perspective of the cellular microenvironment," Annual Review of Biophysics, vol. 41, pp. 519-542, 2012.

[61] D. E. Ingber, "Cellular mechanotransduction: putting all the pieces together again," The FASEB Journal, vol. 20, no. 7, pp. 811-827, 2006.

[62] D. Li, J. Zhou, F. Chowdhury, J. Cheng, N. Wang, and F. Wang, "Role of mechanical factors in fate decisions of stem cells," Regenerative Medicine, vol. 6, no. 2, pp. 229-240, 2011.

[63] C. B. Khatiwala, P. D. Kim, S. R. Peyton, and A. J. Putnam, "ECM compliance regulates osteogenesis by influencing MAPK signaling downstream of RhoA and ROCK," Journal of Bone and Mineral Research, vol. 24, no. 5, pp. 886-898, 2009.

[64] K. Saha, A. J. Keung, E. F. Irwin et al., "Substrate modulus directs neural stem cell behavior," Biophysical Journal, vol. 95, no. 9, pp. 4426-4438, 2008.

[65] A. Banerjee, M. Arha, S. Choudhary et al., "The influence of hydrogel modulus on the proliferation and differentiation of encapsulated neural stem cells," Biomaterials, vol. 30, no. 27, pp. 4695-4699, 2009.

[66] N. D. Leipzig and M. S. Shoichet, "The effect of substrate stiffness on adult neural stem cell behavior," Biomaterials, vol. 30, no. 36, pp. 6867-6878, 2009.

[67] J. P. Winer, P. A. Janmey, M. E. McCormick, and M. Funaki, "Bone marrow-derived human mesenchymal stem cells become quiescent on soft substrates but remain responsive to chemical or mechanical stimuli," Tissue Engineering A, vol. 15, no. 1, pp. 147-154, 2009.

[68] J. Fu, Y. K. Wang, M. T. Yang et al., "Mechanical regulation of cell function with geometrically modulated elastomeric substrates," Nature Methods, vol. 7, no. 9, pp. 733-736, 2010. 
[69] P. M. Gilbert, K. L. Havenstrite, K. E. G. Magnusson et al., "Substrate elasticity regulates skeletal muscle stem cell selfrenewal in culture," Science, vol. 329, no. 5995, pp. 1078 1081, 2010.

[70] J. R. Tse and A. J. Engler, "Stiffness gradients mimicking in vivo tissue variation regulate mesenchymal stem cell fate," PLoS ONE, vol. 6, no. 1, Article ID e15978, 2011.

[71] N. D. Evans, C. Minelli, E. Gentleman et al., "Substrate stiffness affects early differentiation events in embryonic stem cells," European Cells and Materials, vol. 18, pp. 1-13, 2009.

[72] F. Chowdhury, Y. Li, Y. C. Poh, T. Yokohama, N. Wang, and T. S. Tanaka, "Soft substrates promote homogeneous selfrenewal of embryonic stem cells via downregulating cellmatrix tractions," PLoS ONE, vol. 5, no. 12, Article ID e15655, 2010.

[73] M. Nikkhah, F. Edalat, S. Manoucheri, and A. Khademhosseini, "Engineering microscale topographies to control the cell-substrate interface," Biomaterials, vol. 33, no. 21, pp. 5230-5246, 2012.

[74] J. M. Curran, R. Stokes, E. Irvine et al., "Introducing dip pen nanolithography as a tool for controlling stem cell behaviour: unlocking the potential of the next generation of smart materials in regenerative medicine," Lab on a Chip, vol. 10, no. 13, pp. 1662-1670, 2010.

[75] R. J. McMurray, N. Gadegaard, P. M. Tsimbouri et al., "Nanoscale surfaces for the long-term maintenance of mesenchymal stem cell phenotype and multipotency," Nature Materials, vol. 10, no. 8, pp. 637-644, 2011.

[76] E. K. F. Yim, S. W. Pang, and K. W. Leong, "Synthetic nanostructures inducing differentiation of human mesenchymal stem cells into neuronal lineage," Experimental Cell Research, vol. 313, no. 9, pp. 1820-1829, 2007.

[77] M. P. Prabhakaran, J. R. Venugopal, and S. Ramakrishna, "Mesenchymal stem cell differentiation to neuronal cells on electrospun nanofibrous substrates for nerve tissue engineering," Biomaterials, vol. 30, no. 28, pp. 4996-5003, 2009.

[78] J. M. Dang and K. W. Leong, "Myogenic induction of aligned mesenchymal stem cell sheets by culture on thermally responsive electrospun nanofibers," Advanced Materials, vol. 19, no. 19, pp. 2775-2779, 2007.

[79] X. Hu, S.-H. Park, E. S. Gil, X.-X. Xia, A. S. Weiss, and D. L. Kaplan, "The influence of elasticity and surface roughness on myogenic and osteogenic-differentiation of cells on silkelastin biomaterials," Biomaterials, vol. 32, no. 34, pp. 89798989, 2011.

[80] S. Martino, F. D’Angelo, I. Armentano et al., "Hydrogenated amorphous carbon nanopatterned film designs drive human bone marrow mesenchymal stem cell cytoskeleton architecture," Tissue Engineering A, vol. 15, no. 10, pp. 3139-3149, 2009.

[81] E. Martínez, E. Engel, J. A. Planell, and J. Samitier, "Effects of artificial micro- and nano-structured surfaces on cell behaviour," Annals of Anatomy, vol. 191, no. 1, pp. 126-135, 2009.

[82] E. Engel, E. Martínez, C. A. Mills, M. Funes, J. A. Planell, and J. Samitier, "Mesenchymal stem cell differentiation on microstructured poly (methyl methacrylate) substrates," Annals of Anatomy, vol. 191, no. 1, pp. 136-144, 2009.

[83] M. J. Dalby, N. Gadegaard, R. Tare et al., "The control of human mesenchymal cell differentiation using nanoscale symmetry and disorder," Nature Materials, vol. 6, no. 12, pp. 997-1003, 2007.

[84] F. Kantawong, K. E. V. Burgess, K. Jayawardena et al., "Whole proteome analysis of osteoprogenitor differentiation induced by disordered nanotopography and mediated by ERK signalling," Biomaterials, vol. 30, no. 27, pp. 4723-4731, 2009.

[85] M. J. Dalby, D. McCloy, M. Robertson et al., "Osteoprogenitor response to semi-ordered and random nanotopographies," Biomaterials, vol. 27, no. 15, pp. 2980-2987, 2006.

[86] T. Sjöström, M. J. Dalby, A. Hart, R. Tare, R. O. C. Oreffo, and B. Su, "Fabrication of pillar-like titania nanostructures on titanium and their interactions with human skeletal stem cells," Acta Biomaterialia, vol. 5, no. 5, pp. 1433-1441, 2009.

[87] S. Proksch, T. Steinberg, S. Schulz, S. Sauerbier, E. Hellwig, and P. Tomakidi, "Environmental biomechanics substantiated by defined pillar micropatterns govern behavior of human mesenchymal stem cells," Cell Transplantation. In press.

[88] R. McBeath, D. M. Pirone, C. M. Nelson, K. Bhadriraju, and C. S. Chen, "Cell shape, cytoskeletal tension, and RhoA regulate stem cell lineage commitment," Developmental Cell, vol. 6, no. 4, pp. 483-495, 2004.

[89] S. A. Ruiz and C. S. Chen, "Emergence of patterned stem cell differentiation within multicellular structures," Stem Cells, vol. 26, no. 11, pp. 2921-2927, 2008.

[90] K. A. Kilian, B. Bugarija, B. T. Lahn, and M. Mrksich, "Geometric cues for directing the differentiation of mesenchymal stem cells," Proceedings of the National Academy of Sciences of the United States of America, vol. 107, no. 11, pp. 4872-4877, 2010.

[91] L. Q. Wan, S. M. Kang, G. Eng et al., "Geometric control of human stem cell morphology and differentiation," Integrative Biology, vol. 2, no. 7-8, pp. 346-353, 2010.

[92] W. Luo, S. R. Jones, and M. N. Yousaf, "Geometric controlf stem cell differentiation rate on surfaces," Langmuir, vol. 24, no. 21, pp. 12129-12133, 2008.

[93] P. Murray and D. Edgar, "The topographical regulation of embryonic stem cell differentiation," Philosophical Transactions of the Royal Society B, vol. 359, no. 1446, pp. 1009-1020, 2004.

[94] S. Gerecht, C. J. Bettinger, Z. Zhang, J. T. Borenstein, G. Vunjak-Novakovic, and R. Langer, "The effect of actin disrupting agents on contact guidance of human embryonic stem cells," Biomaterials, vol. 28, no. 28, pp. 4068-4077, 2007.

[95] L. D. Markert, J. Lovmand, M. Foss et al., "Identification of distinct topographical surface microstructures favoring either undifferentiated expansion or differentiation of murine embryonic stem cells," Stem Cells and Development, vol. 18, no. 9, pp. 1331-1342, 2009.

[96] D. Sasaki, T. Shimizu, S. Masuda et al., "Mass preparation of size-controlled mouse embryonic stem cell aggregates and induction of cardiac differentiation by cell patterning method," Biomaterials, vol. 30, no. 26, pp. 4384-4389, 2009.

[97] L. A. Smith, X. Liu, J. Hu, P. Wang, and P. X. Ma, "Enhancing osteogenic differentiation of mouse embryonic stem cells by nanofibers," Tissue Engineering A, vol. 15, no. 7, pp. 18551864, 2009.

[98] J. A. Burdick and G. Vunjak-Novakovic, "Engineered microenvironments for controlled stem cell differentiation," Tissue Engineering A, vol. 15, no. 2, pp. 205-219, 2009.

[99] W. J. Nelson, "Adaptation of core mechanisms to generate cell polarity," Nature, vol. 422, no. 6933, pp. 766-774, 2003.

[100] S. Zhang, X. Zhao, and L Spirio, "PuraMatrix: selfassembling peptide nanofiber scaffolds," in Scaffolding in Tissue Engineering, P. X. Ma and J. Elisseeff, Eds., pp. 217238, CRC Press, Boca Raton, Fla, USA, 2005. 
[101] M. W. Tibbitt and K. S. Anseth, "Hydrogels as extracellular matrix mimics for 3D cell culture," Biotechnology and Bioengineering, vol. 103, no. 4, pp. 655-663, 2009.

[102] T. P. Kraehenbuehl, R. Langer, and L. S. Ferreira, "Threedimensional biomaterials for the study of human pluripotent stem cells," Nature Methods, vol. 8, no. 9, pp. 731-736, 2011.

[103] N. L. Nerurkar, W. Han, R. L. Mauck, and D. M. Elliott, "Homologous structure-function relationships between native fibrocartilage and tissue engineered from MSC-seeded nanofibrous scaffolds," Biomaterials, vol. 32, no. 2, pp. 461-468, 2011.

[104] X. Li, H. Liu, X. Niu et al., "The use of carbon nanotubes to induce osteogenic differentiation of human adiposederived MSCs in vitro and ectopic bone formation in vivo," Biomaterials, vol. 33, no. 19, pp. 4818-4827, 2012.

[105] H. Naito, Y. Dohi, W.-H. Zimmermann et al., "The effect of mesenchymal stem cell osteoblastic differentiation on the mechanical properties of engineered bone-like tissue," Tissue Engineering A, vol. 17, no. 17-18, pp. 2321-2329, 2011.

[106] S. H. Park, D. Y. Yang, and K. S. Lee, "Two-photon stereolithography for realizing ultraprecise three-dimensional nano/microdevices," Laser and Photonics Reviews, vol. 3, no. 1-2, pp. 1-11, 2009.

[107] V. Melissinaki, A. A. Gill, I. Ortega et al., "Direct laser writing of 3D scaffolds for neural tissue engineering applications," Biofabrication, vol. 3, no. 4, Article ID 045005, 2011.

[108] A. Ovsianikov, M. Gruene, M. Pflaum et al., "Laser printing of cells into 3D scaffolds," Biofabrication, vol. 2, no. 1, p. 014104, 2010.

[109] M. T. Raimondi, S. M. Eaton, M. M. Nava, M. Laganà, G. Cerullo, and R. Osellame, "Two-photon laser polymerization: from fundamentals to biomedical application in tissue engineering and regenerative medicine," Journal of Applied Biomaterials \& Functional Materials, vol. 10, no. 1, pp. 5666, 2012.

[110] J. H. C. Wang and B. P. Thampatty, "Mechanobiology of adult and stem cells," International Review of Cell and Molecular Biology, vol. 271, pp. 301-346, 2008.

[111] S. Saha, L. Ji, J. J. De Pablo, and S. P. Palecek, "Inhibition of human embryonic stem cell differentiation by mechanical strain," Journal of Cellular Physiology, vol. 206, no. 1, pp. 126137, 2006.

[112] R. L. Mauck, B. A. Byers, X. Yuan, and R. S. Tuan, "Regulation of cartilaginous ECM gene transcription by chondrocytes and MSCs in 3D culture in response to dynamic loading," Biomechanics and Modeling in Mechanobiology, vol. 6, no. 12, pp. 113-125, 2007.

[113] Z. Gong and L. E. Niklason, "Small-diameter human vessel wall engineered from bone marrow-derived mesenchymal stem cells (hMSCs)," The FASEB Journal, vol. 22, no. 6, pp. 1635-1648, 2008.

[114] N. Shimizu, K. Yamamoto, S. Obi et al., "Cyclic strain induces mouse embryonic stem cell differentiation into vascular smooth muscle cells by activating PDGF receptor $\beta$," Journal of Applied Physiology, vol. 104, no. 3, pp. 766-772, 2008.

[115] C. Y. C. Huang, K. L. Hagar, L. E. Frost, Y. Sun, and H. S. Cheung, "Effects of cyclic compressive loading on chondrogenesis of rabbit bone-marrow derived mesenchymal stem cells," Stem Cells, vol. 22, no. 3, pp. 313-323, 2004.

[116] G. H. Altman, R. L. Horan, I. Martin et al., "Cell differentiation by mechanical stress," The FASEB Journal, vol. 16, no. 2, pp. 270-272, 2002.

[117] M. Knippenberg, M. N. Helder, B. Z. Doulabi, C. M. Semeins, P. I. J. M. Wuisman, and J. Klein-Nulend, "Adipose tissue-derived mesenchymal stem cells acquire bone cell-like responsiveness to fluid shear stress on osteogenic stimulation," Tissue Engineering, vol. 11, no. 11-12, pp. 1780-1788, 2005.

[118] N. F. Huang, B. Patlolla, O. Abilez et al., "A matrix micropatterning platform for cell localization and stem cell fate determination," Acta Biomaterialia, vol. 6, no. 12, pp. 4614-4621, 2010.

[119] Y. C. Lim, J. Johnson, Z. Fei et al., "Micropatterning and characterization of electrospun poly( $\varepsilon$-caprolactone)/gelatin nanofiber tissue scaffolds by femtosecond laser ablation for tissue engineering applications," Biotechnology and Bioengineering, vol. 108, no. 1, pp. 116-126, 2011.

[120] E. L. Papadopoulou, A. Samara, M. Barberoglou et al., "Silicon scaffolds promoting three-dimensional neuronal web of cytoplasmic processes," Tissue Engineering C, vol. 16, no. 3, pp. 497-502, 2010.

[121] L. Adamo, O. Naveiras, P. L. Wenzel et al., "Biomechanical forces promote embryonic haematopoiesis," Nature, vol. 459, no. 7250, pp. 1131-1135, 2009.

[122] J. Zhang and J. H. C. Wang, "Production of PGE2 increases in tendons subjected to repetitive mechanical loading and induces differentiation of tendon stem cells into nontenocytes," Journal of Orthopaedic Research, vol. 28, no. 2, pp. 198-203, 2010.

[123] J. Zhang and J. H. C. Wang, "Mechanobiological response of tendon stem cells: implications of tendon homeostasis and pathogenesis of tendinopathy," Journal of Orthopaedic Research, vol. 28, no. 5, pp. 639-643, 2010.

[124] J. Zhang and J. H. C. Wang, "Characterization of differentialproperties of rabbit tendon stem cells and tenocytes," BMC Musculoskeletal Disorders, vol. 11, article 10, 2010.

[125] O. Schätti, S. Grad, J. Goldhahn et al., "A combination of shear and dynamic compression leads to mechanically induced chondrogenesis of human mesenchymal stem cells," European Cells \& Materials Journal, vol. 22, pp. 214-225, 2011.

[126] B. Sen, Z. Xie, N. Case, M. Ma, C. Rubin, and J. Rubin, "Mechanical strain inhibits adipogenesis in mesenchymal stem cells by stimulating a durable $\beta$-catenin signal," Endocrinology, vol. 149, no. 12, pp. 6065-6075, 2008. 


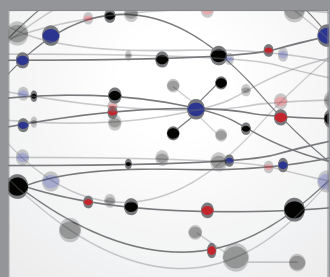

The Scientific World Journal
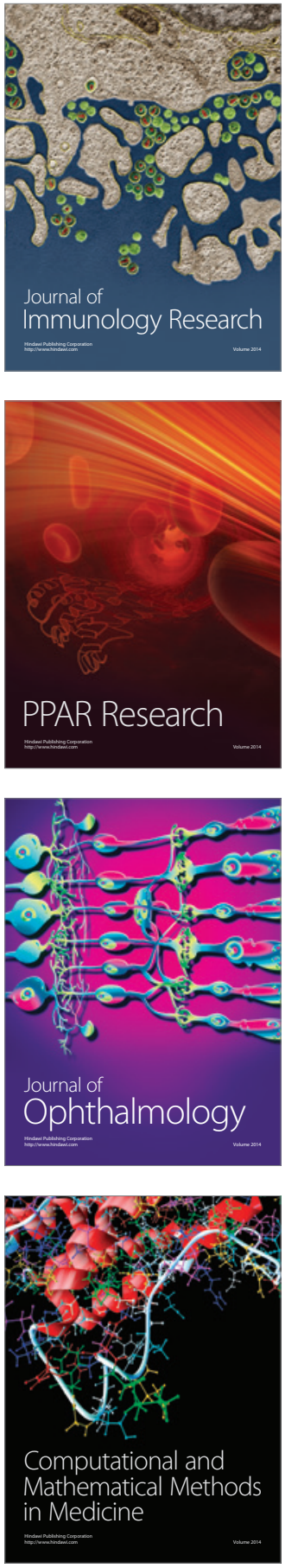

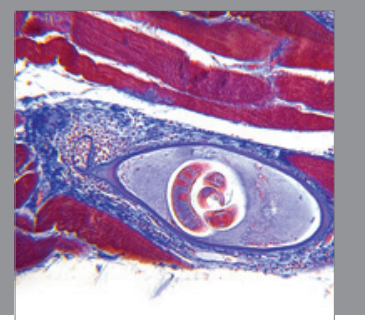

Gastroenterology

Research and Practice
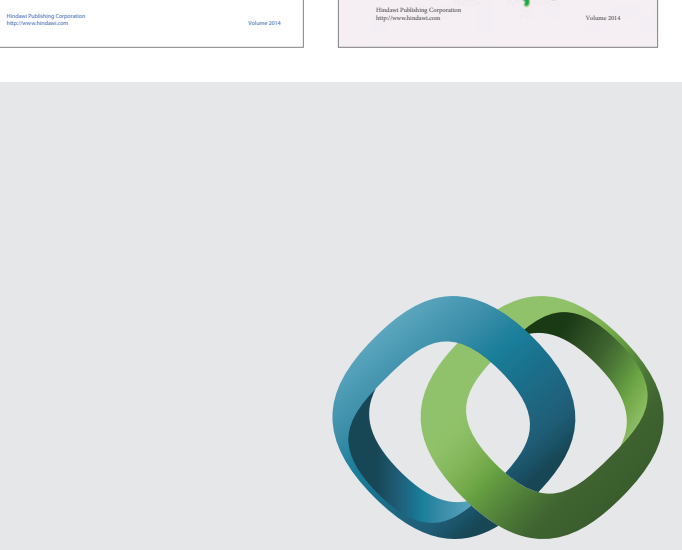

\section{Hindawi}

Submit your manuscripts at

http://www.hindawi.com
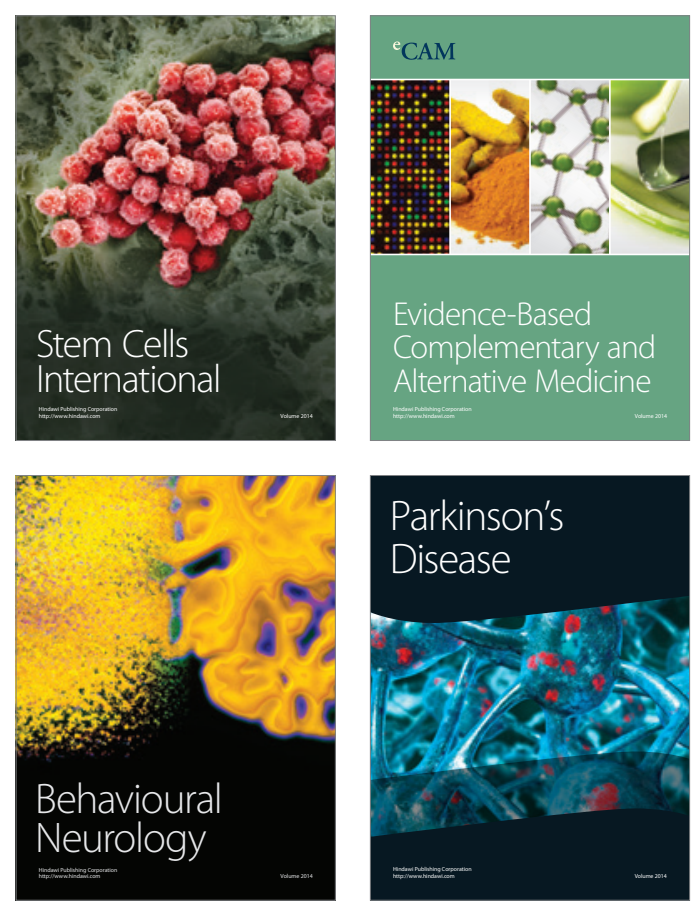

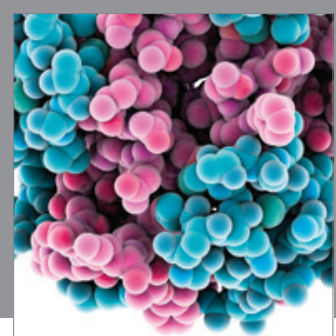

Journal of
Diabetes Research

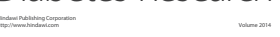

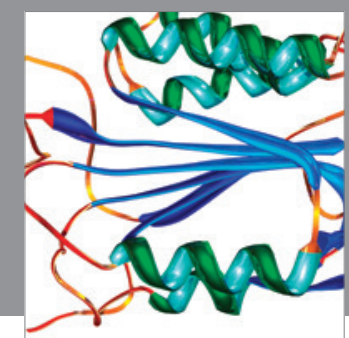

Disease Markers
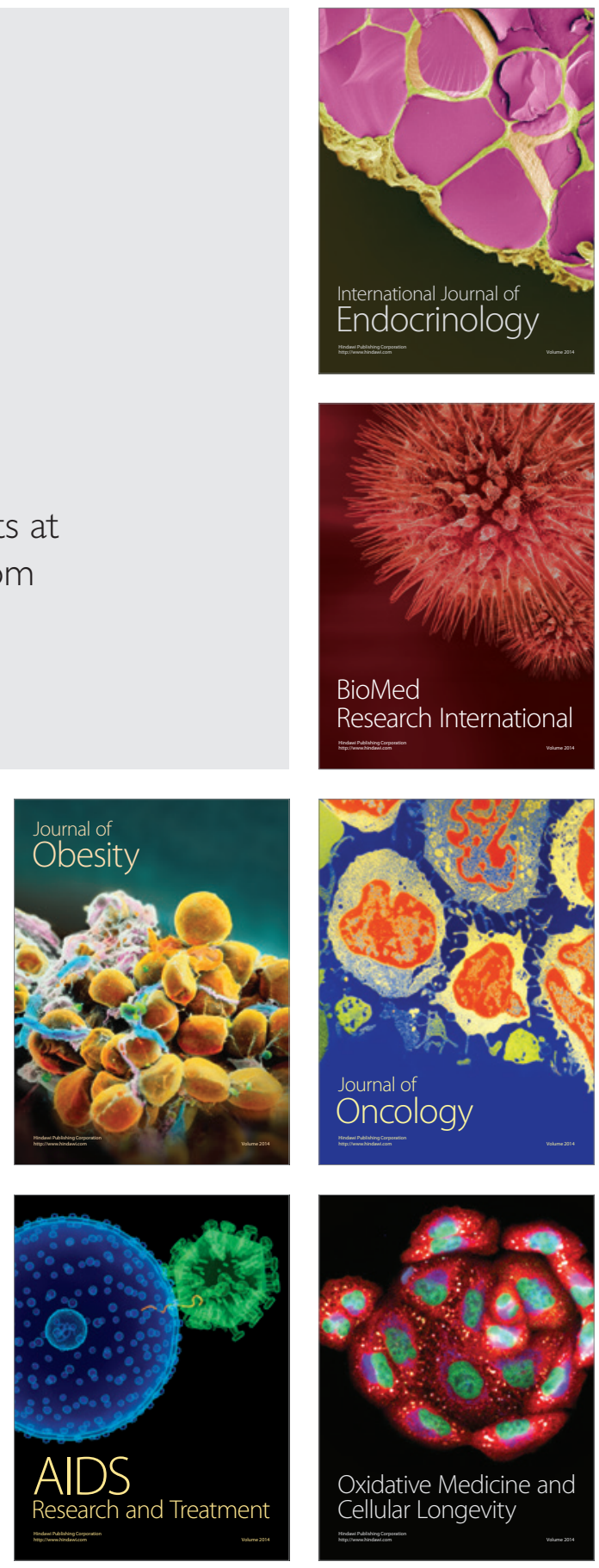